\title{
The Mysterious Calcination of Metals
}

IF, for the various reasons we have advanced, Lavoisier came to suspect, in the summer of 1772 , that air is given off when metallic calxes are reduced, and consequently that it is absorbed when metals are burned or roasted, he had also become aware, at about the same time, of the significant fact that some metals, perhaps all metals that can be burned, gain weight when they are calcined. Here was a phenomenon which the phlogiston theory could not adequately explain; for, according to this widely held theory, burning and calcination were accompanied by a loss of this hypothetical fire principle, whereas an increase in weight should prove that something had been added. This fait capital, as Lavoisier later called it-that the calx of a metal is heavier than the regulus-we know to have been of crucial importance in the crystallization of his thought. He mentioned it in the sealed note of November; and in the Opuscules of 1774 he singled it out as of real importance, as we have seen above. Later still, in his "Réflexions sur le phlogistique," he emphasized the point strongly: 
Suivant Stahl, le phlogistique, le principe inflammable, est un corps pesant; et, en effet, on ne peut pas se former une autre idée d'un principe terreux, ou au moins dans la composition duquel entre l'élément terreux; il a même essayé, dans son traité du soufre, d'en déterminer la pesanteur.

Cette théorie de Stahl sur la calcination des métaux et sur la combustion en général ne rendait pas compte d'un phénomène très-anciennement observé, vérifié par Boyle, et qui est devenu aujourd'hui une vérité incontestable, c'est que tous les corps combustibles augmentent de poids pendant le temps qu'ils brûlent et se calcinent. . . Or, dans le système de Stahl, il s'échappe des métaux, pendant qu'on les calcine, et des corps combustibles qui brûlent, du phlogistique qui est un principe pesant; ils doivent donc perdre une quantité de leur poids au lieu d'en acquérir. ${ }^{1}$

Historians have never doubted the influence of the augmentation effect on Lavoisier's thought and have been well aware of the use he made of it in arguing against the phlogiston theory. But I believe he did not merely think of this later, when seeking to refute the phlogistonists; for, as the reference in the Opuscules suggests, it supplied one of the most significant facts that led him, in the first instance, to suspect the participation of air in the transformation of metals.

But there is a further point worth stressing. Historians of chemistry seem always to have assumed that this fait capital, the augmentation of the calx, was a familiar fact which had been known for well over a century and that it had been widely accepted. Only the blind stubbornness of the adherents of the phlogiston theory, so runs this interpretation, prevented these early chemists from seeing

1 Oeuvres de Lavoisier, II, 625-626. The italics are mine. 


\section{MYSTERIOUS CALCINATION}

how fatal to their cherished theory was this single, wellestablished fact; it was therefore left to the genius of Lavoisier, with his rigorously gravimetric approach to chemistry, to perceive its significance. The matter is not quite so simple as historians of science have believed. Surprisingly enough, when Lavoisier began his study of chemistry, this fait capital had not been firmly established and was far from being generally accepted. It was only proved to everyone's satisfaction by experiments performed, not long before the period we are discussing, by Lavoisier's future disciple, the Dijon lawyer and amateur chemist, Louis-Bernard Guyton de Morveau (1737-1816), a man whom Lavoisier at this time had not yet met but whose work he certainly knew. Guyton's experiments, probably carried out in 1770 , first came to the attention of the scientists of Paris in the years 1771-1772, with consequences that scholars have not fully appreciated. Moreover, the results Guyton obtained, and which proved the augmentation effect beyond a doubt, came to general notice at precisely the moment when the possible role of air in chemical change was beginning to occupy the attention of French chemists.

\section{The Augmentation of the Calx}

It had, of course, long been known that lead-which is readily calcined-increases markedly in weight when by being strongly heated it is transformed into minium (red lead) or litharge; this fact had been frequently noted as early as the sixteenth century. ${ }^{2}$ The augmentation effect

$2 \mathrm{~J}$. H. White, The History of the Phlogiston Theory (London, 1932 ), pp. $33 \mathrm{ff}$., has a general treatment of the augmentation problem. See also J. R. Partington and Douglas McKie, "Historical 


\section{LAVOISIER-THE CRUCIAL YEAR}

soon came to be almost as well known in the case of tin, as we learned from the famous-indeed unwarrantedly famous-Essays of Jean Rey (1630)..$^{3}$ During the seventeenth century this striking phenomenon was reported for a number of other metals; in particular, the so-called "solar calcination" of antimony attracted widespread attention after several writers recorded that when this metal is calcined by the heat of a burning glass its weight increases markedly. This seems to have been first reported in the Basilica antimonii of Hamerus Poppius (1618), an author cited by Rey; ${ }^{4}$ but the most influential account of this solar calcination of antimony was given in 1660 by Nicolas Lefèvre (or Lefebvre) in his Traicté de chymie, a work which was soon translated into English and which evoked considerable interest in the circle of the Royal Society of London. ${ }^{5}$ Not long after, Otto Tachenius in his

Studies of the Phlogiston Theory-I. The Levity of Phlogiston," Annals of Science, 2 (1937), 361-373. A valuable bibliography is given in Crell's Chemische Annalen, I (1795), 287-289 and notes.

3 A facsimile edition of this excessively rare work has been published, with a valuable introduction, by Douglas McKie, The Essays of Jean Rey: A Facsimile Reprint of the Original Edition of 1630 (London, 1951). See also the English version, Essays of Jean Rey, Doctor of Medicine, On an Enquiry into the Cause Wherefore Tin and Lead Increase in Weight on Calcination (1630) (Alembic Club Reprints, no. 11; Edinburgh, 1895).

${ }^{4}$ On Poppius see Kopp, op. cit., III (1845), 120.

5 This translation appeared shortly after Lefèvre arrived in England to serve Charles II as royal apothecary and professor of chemistry. It was dedicated to the king, under the title: A Compleat Body of Chymistry . . . by Nicasius le Febure, Royal Professor in Chymistry to his Majesty of England, and Apothecary in Ordinary to His Honorable Household. Rendred into English by P. D. C. Esq. one of the Gentlemen of his Majesties Privy Chamber (London, 1664). Lefèvre's arrival in England and the appearance of the trans- 


\section{MYSTERIOUS CALCINATION}

Hippocrates chimicus (1666) reported the successful calcination of antimony in a "Glass-mens oven, or Furnace," noting the augmentation and the fact that the original weight could be recovered upon reduction. ${ }^{6}$

In Paris the solar calcination of antimony was confirmed about 1667 by Samuel Cottereau, Sieur Du Clos, one of the founding members of the Académie royale des sciences, who also reported the increase in weight of other metals-lead, tin, iron, and copper-during their conversion into calxes. ${ }^{7}$ Even more persuasive evidence for the generality of the phenomenon of augmentation was supplied by the experiments of the great Robert Boyle. In his Essays of Effluviums (1673) he showed-by heating bits of metal in open crucibles over a sulphur flame and in a cupellation furnace-that an increase in weight could be detected in calcined copper, tin, lead, steel filings, zinc or spelter filings, and tutenag. ${ }^{8}$ To the list of sub-

lation of his book stimulated an interest in these problems on the part of members of the Royal Society like Jonathan Goddard and Robert Boyle. See Thomas Birch, History of the Royal Society (London, 1756-1757), I, 19-20, 445, 452. A good account of Lefèvre is given in John Read, Humour and Humanism in Chemistry (London, 1947), pp. 101-114.

${ }^{6}$ This work and his Hippocraticae medicinae clavis manuali experientia in naturae fontibus elaborata, etc. (1669) were published together in English as Otto Tachenius. his Hippocrates Chymicus ... with his Clavis thereunto. Translated by J. W. (London, 1677). See especially this translation, p. 62.

${ }^{7}$ For these experiments see J. B. Duhamel, Regiae scientiarum academiae historia (Paris, 1698), pp. 13-14. On Du Clos see the sketch by Condorcet in Oeuvres de Condorcet, ed. A. Condorcet O'Connor and F. Arago; II, 38-39. According to Homberg, Du Clos calcined antimony using "un des miroirs ardens de l'observatoire." See Mém. Acad. roy. sci. for 1705 (1706), p. 94.

8 "New Experiments to Make Fire and Flame Ponderable," in 
stances studied by Boyle there was soon added mercury. Wilhelm (or Guillaume) Homberg (1652-1715), a chemist of the Academy of Sciences, successfully confirmed the solar calcination of antimony, using the great Tschirnhausen lens acquired by the Duc d'Orléans, and in the paper in which he described these results he recorded that when mercury is converted into a red powder by long heating the powder becomes heavier than the metal. ${ }^{9}$

Thus by the end of the seventeenth century there was little reason for chemists to doubt the reality of the augmentation effect in the calcination of a number of different metals. Whereas Nicolas Lémery, in his influential Cours de chymie (1675), mentioned the increase in weight of lead and the regulus of antimony, and in later editions of this work added a reference to tin, ${ }^{10}$ other writers did not hesitate to assert the generality of the phenomenon. Among these were the Newtonian chemist, John Freind, in his Praelectiones chymicae (1709) ${ }^{11}$ and the great

The Works of the Honourable Robert Boyle, III, 341-346. For a summary of these experiments see Marie Boas, Robert Boyle and Seventeenth Century Chemistry (Cambridge, 1958), pp. 198-200; and Douglas McKie in Science Progress, 29 (1934), $253 \mathrm{f.}$

${ }^{9}$ Mém. Acad. roy. sci. for 1705 (1706), pp. 92-94. Louis Lémery (1677-1743), who advanced a theory similar to Homberg's and attributed the gain in weight of calcined metals to the addition of "matière de lumière," states that the effect is generally recognized for the regulus of antimony, lead, tin, and even mercury. See his "Conjectures et réflexions sur la matière du feu ou de la lumière," Mém. Acad. roy. sci. for 1709 (1711), pp. 400-418.

${ }^{10}$ See Nicolas Lémery, Cours de chymie (5th ed.; Paris, 1683), pp. 119-120 and 225. This edition still is silent on the augmentation of tin, but see the edition of 1756 described below, pp. 122-123, where the new paragraph on tin is found on p. 95.

${ }^{11}$ John Freind, Praelectiones chymicae (3rd ed.; Leyden, 1734), p. 12. The English version reads: "So Lead, and all other Metals, 
pundit of the phlogiston theory, Georg Ernst Stahl, whose opinion was echoed by his disciples. ${ }^{12}$

The earliest explanation given of this mysterious phenomenon-mysterious because, as Biringuccio remarked, it is the nature of fire "to consume everything with a diminution of substances" ${ }^{13}$ - was that it was caused by the removal of some lighter constituent, air or celestial heat. This early view, advanced with individual variations by Biringuccio, Cardan, and Scaliger, was not popular in the seventeenth century, though Cardan's version of the theory is echoed by Kunckel. ${ }^{14}$ It was most generally assumed, before the advent of the phlogiston theory, that the augmentation must be due to the addition of some

gain in their weight by Calcination: for if an Ounce of Lead be reduc'd to a Calx, by the Flame of Spirit of Wine, it will increase above a Scruple in weight" (Chymical Lectures [2nd ed.; London, 1729], p. 25).

12 Zufällige Gedancken und nützliche Bedencken über den Streit von dem sogenannten Sulphure, etc. (Halle, 1718), p. 329; Partington and McKie (loc. cit., p. 369, note 16) give the crucial lines. I have also used d'Holbach's translation (Traité du soufre [Paris, 1766]), where we read: "car dans les metaux inflammables elle [phlogiston] produit un effet très-opposé, puisque leurs chaux deviennent plus pesantes, \& redeviennent plus légeres par son addition" (p. 277). Elsewhere it is less evident that Stahl believed in the generality of the phenomenon, for he speaks only of lead, tin, and the regulus of antimony in his Fundamenta chymiae (2nd ed.; Nuremberg, 1746-1747), II, 374 and 507-508. But one of Stahl's earliest French disciples, J. B. Senac, wrote: "L'Augmentation des corps calcinez prouve que les parties se divisent \& s'éloignent les unes des autres." See Nouveau cours de chymie, suivant les principes de Newton \& de Sthall (2nd ed.; Paris, 1737), I, 160.

${ }^{13}$ The Pirotechnica of Vannochio Biringuccio, trans. by Cyril Stanley Smith and Martha Teach Gnudi (New York, 1943), pp. 5859.

${ }^{14}$ Partington and McKie, loc. cit., pp. 369-370. 
external substance possessing weight. Today the most often cited explanation is the one that Jean Rey gave in his Essays-that the augmentation is due to the addition of air to the metal. But Rey's opinion has frequently been misinterpreted. His explanation is physical rather than chemical, for what he describes is the adherence of air to the calx that the fire has already produced in some unspecified manner; just as, he says, wet sand is heavier because the water moistens and adheres to the grains. Rey's theory did not attract much attention, but it may not have been as totally ignored by chemists in the seventeenth century as historians generally believe..$^{15}$ Nevertheless, the most popular theory was that which ascribed the augmentation to the fixation of corpuscules ignés, i.e., of ponderable particles of fire or light. This was the view put forth in the writings of Nicolas Lémery, Otto Tachenius, Moïse Charas, and Robert Boyle. John Mayow, for his part, combined this with his favorite theory of an aerial niter and attributed the increase in weight of calcined antimony to the nitroaerial and igneous particles

${ }^{15}$ Birch records that when Dr. Goddard reported to the Royal Society in July, 1664, that he had found antimony to decrease in weight when exposed to a burning glass instead of increasing, "Mr. Boyle affirm'd, that he had like success in such an experiment; but that Monsieur Le Febure, who asserted the increase of antimony calcined by the sun, hearing of such success with him, answered, that it had not been calcined enough to reduce to a fixed salt for the imbibing of air" (Birch, History of the Royal Society of London, I, 452). See also Tachenius' Clavis where the author attacks the notion that the increase in weight of lead can be due to air. He does not mention Rey but attributes this theory (as the English version gives it) to "Deans with their Fellows" and to "your Doctorships." See Otto Tachenius. his Hippocrates Chymicus, p. 62. 
fixed in it by the solar rays of the burning glass. ${ }^{16}$ Somewhat similar was the view of $\mathrm{Du}$ Clos, who imagined that the gain in weight came from impurities or sulphurous particles in the air.

Yet despite all this evidence there was by no means unanimity that the augmentation effect was invariably encountered or that it was really significant. Simon Boulduc (1652-1729), a chemist of the early Academy of Sciences, reported that antimony lost weight when calcined in an open vessel; ${ }^{17}$ and John Francis Vigani, the Italian scientist who briefly assisted Newton in his chemical experiments, announced in his Medulla chymiae (1693) that when he calcined antimony with a burning glass he found a loss of weight, and he insisted that those who claimed the contrary were in error. ${ }^{18}$ Early in the eighteenth century Nicolas Hartsoeker (1656-1725) carried out experiments which convinced him that calcination with the burning glass could produce no increase in weight of lead, tin, or other metals. ${ }^{19}$

Even those persons, and they were well in the majority, who did not doubt that lead, tin, and antimony showed the augmentation effect, were far from sure that the

${ }^{16}$ Tractatus quinque medico-physici (Oxford, 1674), pp. 28-29. Cf. John Mayow, Medico-Physical Works (Edinburgh and Chicago, 1908), pp. 20-21.

17 Duhamel, op. cit., p .14, where we read: "Nam D. Bouleduc nuper in Academia testatus est antimonium crudum in vase fictili calcinatem pondere imminutum fuisse."

18 Vigani's views are cited by Baron in his edition of Lémery's Cours de chymie (Paris, 1756), p. 268, note h.

19 Douglas McKie, "Béraut's Theory of Calcination (1747)," Annals of Science, 1 (1936), 272 and note 15. 
effect was chemically significant and thought it might result from the addition of impurities. This, indeed, had been suggested by Caesalpinus in the sixteenth century. But it was Hermann Boerhaave who most effectively confused the issue. Having shown in a famous experiment that an iron bar weighed no more when it was heated than when it was cold, he concluded that heat or the matter of fire is destitute of weight. The augmentation effect could hardly, then, be attributed to igneous corpuscles, as so many had believed, or to the particles of fire or light. That an increase in weight could be observed in the case of bodies "abounding in a rapacious sulphur, as antimony, lead, tin, iron, and orpiment," he did not deny; yet he was inclined to ascribe it to the "acid of the fewel" imbibed by the metal or to particles communicated from glass or earthen vessels or from the iron ladles with which the melt was sometimes stirred. ${ }^{20}$

Boerhaave's great influence and authority served to encourage doubts that the augmentation phenomenon was general and seemed to deflate its significance. When Voltaire, early in 1737, resolved to compete for the prize offered by the Academy of Sciences for the best essay on the nature of heat, he requested a correspondent in Paris to send him Boerhaave's Chemistry, to find out the opinion of the chemists Geoffroy and Grosse concerning the experiments of Lémery the younger and Homberg, and

20 Shaw-Boerhaave (1741), I, 339-340. Boerhaave cites the experiments of Boyle, Du Clos, and Homberg in support of the role of igneous particles but remarks that the experiments of Boulduc strongly favor the contrary opinion. It would seem that Boerhaave first accepted the theory of igneous particles but that his experiment on the iron bar shook his confidence. Cf. P. Shaw and E. Chambers, New Method of Chemistry, I, 79. 


\section{MYSTERIOUS CALCINATION}

to learn whether they believed Homberg's experiments on calcination more worthy of credence than Boerhaave's on the iron bar. ${ }^{21}$ This apparent contradiction still troubled Voltaire when he produced his Essai sur la nature $d u$ feu (1740), although he ended by taking the position that the calcination experiments proved that fire has weight. ${ }^{22}$

The same problem was treated by Mme du Châtelet, Voltaire's friend, mistress, and scientific associate. In her Dissertation sur la nature et la propagation du feu (1744) she contrasts the positive results of Boyle and Homberg with the negative ones of Boulduc and Hartsoeker, and she notes the hesitations of Boerhaave. She concludes, unlike Voltaire, that fire is very nearly weightless and that the weight increase in calcination experiments must be due to the intrusion of extraneous matter. ${ }^{23}$

The French chemists shared these doubts. Venel's article on calcination in Diderot's Encyclopédie makes only the cautious statement that "certain metallic substances" show the augmentation effect and that this effect is especially remarkable in the case of lead. ${ }^{24} \mathrm{P}$. J. Macquer, who had stated in his Elémens de chymie pratique (1751) that the calxes of the imperfect metals, notably lead, increase in weight on calcination, ${ }^{25}$ significantly omitted any such

21 Voltaire, Oeuvres, ed. Moland, XXXIV, 253, 277, 285, 292.

22 Essai sur la nature du feu, et sur sa propagation (Paris, 1740). See also Oeuvres, ed. Moland, XXII, 279-325.

${ }^{23}$ Dissertation sur la nature et la propagation du feu (Paris, 1744), pp. 23-34.

${ }^{24}$ Encyclopédie, II (1751), art. "Calcination."

${ }^{25} \mathrm{P}$. J. Macquer, Elémens de chymie pratique (Paris, 1751), I, 309-310. Macquer is distinctly cautious about this "singular phenomenon." Many theories have been advanced to explain it, but none have proved satisfactory, so he proposes to offer none. See also 
statement from the first edition of his Dictionnaire de chymie (1766). If the influence of Boerhaave cannot be demonstrated in the case of Macquer, it is clearly evident in the case of his younger disciple, Antoine Baumé (17281804), who gives a summary of Boerhaave's discussion of the calcination problem and agrees with Boerhaave that “on n'a pas pris sur cette matière toutes les précautions convenables pour s'assurer de la cause de cette augmentation." ${ }^{26}$ More significant still, the elder Rouelle evidently did not consider the weight effect worthy of serious attention; when he discusses the calcination of lead and tin he makes no reference to the augmentation of the calx, and in the section of his lectures that treats of antimony he insists that the increase in weight of the calx is only apparent and is due to the greater density of the calx. ${ }^{27}$ This theory, put forward by Juncker and derived by him from Kunckel, enjoyed considerable popularity in the eighteenth century. ${ }^{28}$

The prevailing hesitation and confusion was clearly summed up by the chemist and physician, Théodore Baron (1715-1768), in the new edition of Lémery's Cours de chymie, which he published in 1756. To Lémery's discussion of the calcination of lead, Baron appends a long note in which Robert Boyle is credited with having been the

Elements of the Theory and Practice of Chemistry, translated from the French of M. Macquer (London, 1758), I, 388-389.

26 A. Baumé, Manuel de chimie (Paris, 1763), pp. 31-32. On Baumé see Balteau, op. cit., V (1951), 934-935.

27 "Cours de chymie de $M^{r}$ Rouelle," Bordeaux MS, pp. 970 and 1031-1032.

${ }^{28}$ For a discussion of this theory see Metzger, Newton, Stahl, Boerhaave, pp. 187-188; and Partington and McKie, loc. cit., pp. 369-370. 


\section{MYSTERIOUS CALCINATION}

first to speak of "cette augmentation de poids qui arrive aux matieres métalliques par la calcination." Boyle's results were confirmed by the experiments of Homberg and Lémery the younger, and their doctrine "est aujourd'hui celui du plus grand nombre des Physiciens." But Boerhaave, it is pointed out, had raised some serious difficulties, and Baron proceeds to enumerate them almost exactly as Boerhaave himself did, stressing that the weight effect was probably due to impurities, even in Boyle's experiments in closed vessels where particles of glass may have been picked up by the metal. Moreover, he emphasized, not all metals show this increase in weight, and he concludes: "Il suit de tout ce qui vient d'être dit, que le plus sage parti est de suspendre son jugement, jusqu'à ce que de nouvelles expériences nous ayent fourni de nouveaux éclaircissemens." ${ }^{29}$

Much stronger opposition was expressed by two German chemists. Rudolph Augustin Vogel (1724-1774), a versatile if second-rank scientist and physician of Göttingen, published in 1753 a brief Latin paper in which he sought to review the whole question. ${ }^{30}$ After a valuable survey of what had been written on the subject, he concluded from the evidence of his own experiments that only lead shows the augmentation effect; other metals, he thought, fell into two groups: a small one, which included tin and copper, showed no change in weight on calcina-

29 Page 113, note a.

30 Experimenta chemicorum de incremento ponderis corporum quorundam igne calcinatorum examinat (Göttingen, n.d. [1753]). I have not seen the original, the title of which I have given from Bolton, but have used the edition with a slightly different title in $R u$ dolphi Augustini Vogel Opuscula Medica Selecta (Göttingen, 1768), pp. 53-68. 
tion; a much larger group, including zinc and antimony, displayed a small decrease.

Much the same conclusion was reached a decade later by the Alsatian chemist, apothecary, and physician, Jacob Reinbold Spielmann (1722-1783), a man best remembered as Goethe's chemistry teacher during the Strasbourg days. ${ }^{31}$ Spielmann's Institutiones chemiae appeared in 1763, with a second edition in 1766; a French translation by Cadet de Gassicourt (Lavoisier's collaborator in the diamond experiments) was published four years later. Even French chemists whose Latin was weak or wanting could now readily learn that Spielmann refused to admit any increase in weight when metals are calcined, except in the case of lead:

On a observé que . . . la calcination ne faisoit qu'augmenter le poids du plomb; phénomène que de grands artistes ont observé relativement à d'autres fossiles. Mais, sur ce dernier point, ils éprouvent des contradictions de la part de quelques auteurs célèbres. Je suis, d'après mes Expériences, fondé à etre de l'avis de ces demiers. ${ }^{32}$

From the evidence given above we can readily understand how Guyton de Morveau could write in 1772 that, while nobody doubted that lead gains about 10 per cent

${ }^{31}$ On Spielmann see Ferguson, op. cit., II, 394. Spielmann's Institutiones was one of the books bought by Lavoisier from König, the Strasbourg bookseller, on the occasion of the famous mineralogical trip to the Vosges in 1767. See Oeuvres de Lavoisier-Correspondance, I (1955), 98.

32 Instituts de chymie de M. Jacques-Reinbold-Spielmann. Traduits du latin, sur la seconde Edition, par M. Cadet le jeune (Paris, 1770), II, 119-120. This passage was later cited, but somewhat inaccurately, by Guyton de Morveau. 


\section{MYSTERIOUS CALCINATION}

in weight when it is calcined, it was by no means clear what happened with other metallic calxes: "Les Auteurs sont en quelque sorte partagés sur ce fait." 33

\section{The Experiments of Guyton de Morveau}

Louis-Bernard Guyton de Morveau (1737-1816), a man six years Lavoisier's senior, was already by 1772 esteemed in his native Dijon as a lawyer of ability, a writer of some local reputation, and a member of that city's scientific and literary academy. If known at all outside his Burgundian province, it could only have been for his literary, rather than any scientific, achievements, especially perhaps for his Mémoire sur l'éducation publique, a plea for free, public, secular education, which he published in 1764 and which was even translated into Spanish. It was inspired, like the similar but better-known work of La Chalotais, by the suppression of the Jesuit order and the ensuing crisis in French education. ${ }^{34}$

Guyton was thirty before he entered seriously on a scientific career, ${ }^{35}$ although he seems to have begun some

${ }^{33}$ Digressions académiques, pp. 7-8. For a discussion of this book see below, note 47. I have not seen N. A. Becher, De igne b gravitate calcis metallicae (Ingolstadt, 1772), cited in Crell, loc. cit., or J. A. Carl's De igne et gravitate calcis metallicae (Ingolstadt, 1772), mentioned by Crell and in Gmelin, Geschichte der Chemie, III, 475. Neither work appeared in time to influence Guyton.

${ }^{34} \mathrm{He}$ had also published an Eloge du président Jeannin (Paris, 1766) and some legal discourses.

${ }^{35}$ On Guyton de Morveau see Georges Bouchard, GuytonMorveau, chimiste et conventionnel (1737-1816) (Paris, 1938). This can still be supplemented on a number of points by A. B. Granville, "An Account of the Life and Writings of Baron Guyton de Morveau," Journal of Science and the Arts, 3 (1817), 249-296, a work that also appeared separately (in- $8^{\circ}$, London, 1817). 
years earlier to teach himself chemistry out of Macquer's books and Baumé's Manuel de chimie (1763). From Baumé, who sold pharmaceuticals and chemical supplies in Paris and had what was almost a small factory, Guyton ordered reagents and chemical apparatus; and by 1768 he began equipping in his home that impressive laboratory and mineralogical cabinet which later evoked the admiration of Arthur Young. It was perhaps in July of that year that Guyton first met Macquer and Baumé on a trip to Paris "for the purpose of visiting the scientific establishments of that metropolis, and purchasing books, preparations, and instruments, which he still wanted to enable him to pursue his favorite study." 36

Guyton's first scientific paper of importance, his "Mémoire sur les phénomènes de l'air dans la combustion," was read before the Academy of Dijon on December 11, 1768. The topic is significant, and so was Guyton's approach to it; together they reveal once again how allpervasive the influence of Stephen Hales had come to be, for Guyton tried to show, in opposition to Hales, that air was not consumed when substances burn and that its role in combustion, as nearly everybody believed, is purely mechanical. ${ }^{37}$

36 Granville, loc. cit., p. 259.

37 Mémoires de l'Académie des sciences, arts et belles-lettres de Dijon, I (1769), 416-436. A summary of Guyton's paper appeared in the Mercure de France for August, 1769, pp. 150-156. The Mercure account says that Guyton presented this paper on December 11,1768 , in the lecture room of the university. But Bouchard (op. cit., pp. 52 and 77) gives the date as January 8, 1768, and records a somewhat different title: "Dissertation sur l'action de l'air dans la combustion des corps." The title I have adopted is that found in the Dijon Mémoires and echoed in the Mercure. Guyton later admitted the manipulative defects involved in these early experiments. See 


\section{MYSTERIOUS CALCINATION}

A well-publicized controversy, in which a member of his own Dijon Academy took a leading part, attracted Guyton to the calcination problem. This episode has been carefully studied ${ }^{38}$ and needs only to be summarized here. In 1764, at a public session of the Academy, Chardenon, a Dijon physician of whom very little is known, ${ }^{39}$ presented a paper entitled "Sur la cause de l'augmentation du poids des substances métalliques calcinées." Without questioning the reality or the generality of the phenomenon of the augmentation of the calx, Chardenon set himself the task of explaining it. He rejected out of hand, as already well enough disproved, the theory that particles of fire become lodged in the metal and make it heavier; but he devotes much space to refuting the theory favored by Du Clos, and elaborated by a certain Père Béraut in 1747 , that foreign corpuscles in the air attach themselves to bodies exposed to calcination and in this manner increase their weight. Chardenon's own explanation invoked the phlogiston theory. Phlogiston, he wrote, is nothing but fire; it is characterized by an inherent lightness, a centrifugal tendency toward the outer reaches of

his article "Air" in Encyclopédie méthodique-Chimie, I (1786), 701.

${ }^{38}$ Partington and McKie, loc. cit., pp. 373-379.

39 Chardenon, an agrégé of the Faculty of Medicine at Dijon, was an associé of the Academy in 1744 and became a full member (pensionnaire) in 1747. One of the secretaries of the Academy, he had worked with Richard de Ruffey and Claude Gelot in drafting the new statutes of 1762 . In all, he made some thirty communications to the Academy. See Ph. Milsand, "Notes et documents pour servir à l'histoire de l'Académie des sciences, arts et belles-lettres de Dijon," in Mém. Acad. Dijon, 2nd ser. 16 (1871), 1-29; and Roger Tisserand, Au Temps de l'Encyclopédie-L'Académie de Dijon de 1740 d 1793 (Vesoul, 1936). 
the universe. When combined with a solid, the phlogiston gives "wings to the earthly molecules"; conversely, when the phlogiston is lost during calcination, the metal, deprived of this uplifting force, increases in weight. ${ }^{40}$

An account of Chardenon's paper appeared in the Mercure de France in the summer of 1765. This elicited a strong but amiable defense of Père Béraut by an apparently pseudonymous correspondent; it took the form of a letter printed in the Journal des sçavans for January, 1768. In it the writer pokes fun at the Dijon doctor's spritely particles, ridicules the idea that a substance can gain weight by losing something and without the addition of new particles, and concludes that "M. Chardenon should have arrayed against him all the astronomers and all the physicists who believe in universal gravitation." 41

Chardenon replied to this letter by an intemperate

${ }^{40}$ Mercure de France for July, 1765 (II, 127-134). As published by the Dijon Academy, Chardenon's paper bore the title "Mémoire sur l'augmentation de poids des métaux calcinés," Mém. Acad. Dijon, 1 (1769), $303 \mathrm{f}$. For the Jesuit Père Béraut (or Béraud) see McKie, "Béraut's Theory of Calcination," loc. cit., 1 (1936), 269293. For Béraut's relationship to the Academy of Bordeaux, see P. Barrière, L'Académie de Bordeaux (Bordeaux and Paris, 1957), passim.

${ }^{41}$ Journal des ş̧avans, December, 1767, pp. 889-894. The letter is signed "Ribapotme Prêtre," and is dated Bordeaux, July 20, 1765. Partington and McKie (loc. cit., p. 374, note 35) believe this pseudonymous letter to have been written by Père Béraut himself. This is at least doubtful, for he is referred to in the letter as the "célèbre Professeur de Mathématiques au Collège de Lyon." There is no evidence that Béraut had left Lyons for Bordeaux, though we know he taught at Lyons from 1740 until 1762 when the Jesuit schools were closed. See F. de Dainville, "L'enseignement des mathématiques dans les collèges Jésuites de France du XVIe au XVIII e siècle (II)," Revue d'histoire des sciences, 7 (1954), 115. 
address delivered to the Academy of Dijon. We had best draw a veil over this rejoinder, for Chardenon casts doubt upon his antagonist's motives and his devotion to truth and gives anger full reign. ${ }^{42}$

Though he was troubled by Chardenon's fanciful theory, which would necessitate abandoning the accepted principles of physics, Guyton de Morveau nevertheless rallied to his colleague's side in the controversy, discussed the problem with him, and offered to share in research which might clarify matters.$^{43} \mathrm{He}$ was convinced that the whole question needed careful examination and hoped to be able to salvage the phlogiston theory without abandoning the doctrine of attraction, which, the reader may remember, was to play such a large part in his later system of chemistry. As his modern biographer puts it: "Guyton entreprit donc de justifier Stahl sans attaquer Newton." 44

Guyton's investigations were probably begun soon after the death of Chardenon, which occurred sometime in 1769, if not while his elder colleague was still alive. ${ }^{45}$ At all events, in December, 1770, Guyton presented to the Academy of Dijon a memoir entitled "Dissertation sur le phlogistique considéré comme corps grave et par rapport aux changements de pesanteur qu'il produit sur les

${ }^{42}$ Journal des sçavans, September, 1768, pp. 648-658.

43 “C'est ainsi que j'en ai souvent parlé à $M$. Chardenon, en lui offrant de partager le travail. Une santé toujours languissante \& des occupations trop continues ne lui ont pas permis de s'y livrer; sa mort m’a laissé la tâche toute entière" (Digressions académiques, p. 5).

${ }^{44}$ Bouchard, op. cit., p. 154.

${ }^{45}$ It is not unlikely that Guyton's paper of 1768 on the role of air in combustion may have been stimulated by the controversy concerning the role of air in calcination. 


\section{LAVOISIER-THE CRUCIAL YEAR}

corps auxquels il s'unit." ${ }^{46}$ This was later published as the first and longest of three essays that together make up Guyton's first scientific book, the Digressions académiques (1772). ${ }^{47}$ The essay contains some interesting and valuable experimental results as well as Guyton's own phlogistic explanation of the gain in weight of calcined metals.

Guyton's "Dissertation sur le phlogistique," the first essay of the Digressions, has been undeservedly neglected by historians of chemistry who, if they mention it at all, ignore the historical and experimental parts and are satisfied to ridicule Guyton's far-fetched theory. ${ }^{48}$ Yet it is my

${ }^{46}$ Bouchard, ibid.

${ }^{47}$ Digressions Académiques, ou Essais sur quelques sujets de Physique, de Chymie do d'Histoire naturelle. Par M. Guyton de Morveau, Avocat-Général au Parlement de Dijon, Honoraire de l'Académies des Sciences, Arts \& Belles-Lettres de la même Ville, Correspondant de l'Académie Royale des Sciences de Paris. A Dijon, Chez L. N. Frantin, 1762 [sic]. This date is a manifest misprint (for the approbation is of March 19, 1772), but it occurs in most copies. W. A. Smeaton reports that two copies, his own and one in the library of the Institut de France, have a corrected title page with the proper date. See his article "L. B. Guyton de Morveau (1737-1816)," Ambix, 6 (1957), 18-34. Guyton's book is uncommon; but Smeaton lists six copies in Parisian libraries, one in the Patent Office, London, and one in the library of the University of Edinburgh. In the United States there are copies in the library of the American Philosophical Society, Philadelphia, at Stanford University, and in the private collection of Denis I. Duveen of New York City.

48 The standard histories of chemistry generally pass over the Digressions in silence; Kopp and Hoefer merely cite the title of the book; but Thomas Thomson (History of Chemistry [2nd ed.; London, n.d.], II, 179) praises it in general terms. Students of Lavoisier, with the exception of Max Speter, have ignored the book; Maurice Daumas (Lavoisier [Paris, 1941], p. 98) mentions it only to remark on the author's "explication du phlogistique toute 


\section{MYSTERIOUS CALCINATION}

contention that Lavoisier owed much to this work, more than he openly acknowledged, for it was Guyton who first proved to the general satisfaction of his contemporaries that all calcinable metals do increase in weight when transformed into their calxes. ${ }^{49}$ For this reasonand because of the rarity of the book in which it is published-I feel justified in giving a précis of its contents.

The "Dissertation," the only essay of the Digressions académiques I shall discuss, is made up of five chapters. The first ("Quelles sont les substances dont le poids augmente réellement par la calcination") is divided into two

personelle." Smeaton, in his recent paper (loc. cit., pp. 21-22), alludes to the calcination experiments without comment; he stresses, however, the importance for affinity theory of the "Essai physicochymique sur la dissolution et la crystallization," which he proposes to analyze in a forthcoming paper.

49 In only two places have I found Guyton's experiments on calcination given their due. Bouchard (op. cit., p. 154) speaks of Guyton's review of earlier work on the augmentation problem as "un exposé fort érudit," and describes the experimental part of the memoir as "importante et sévèrement conduite." Partington and McKie (loc. cit., p. 389), though chiefly concerned with Guyton's theory of the weight increase, remark that he had "established a fact doubted by many and disputed by others" and call the work "a most notable and historical contribution to chemical literature." They promise detailed consideration of the Digressions in a later paper, but this does not seem to have been published; they do not suggest any direct influence of Guyton on Lavoisier, and it is interesting that Douglas McKie makes no mention of the Digressions and its possible influence in his Antoine Lavoisier (1952). Max Speter alone seems to have suggested that a reading of the Digressions may have influenced Lavoisier, but he refers only to the passage where Guyton records the gain in weight of burned phosphorus. See his "Lavoisierana," Chemiker-Zeitung, 55 (1931), 994, and below, p. 172. 
sections devoted to the history of the augmentation problem; ${ }^{50}$ then follow a methodological section ("Principes pour juger \& concilier les divers effets des calcinations") ${ }^{51}$ and a section of fifteen pages in which he describes his own experiments ("Expériences répétées d'après ces principes"). ${ }^{52}$ Of the later chapters, devoted to discussing earlier explanations of the phenomenon and to presenting his own theory, I shall say little, because this part of the book has been carefully analyzed by others..$^{53}$ It was these later chapters which admittedly created the greatest stir at the time and which-to most modern writers who allude to Guyton's book-have seemed to sum up the importance, or rather the futility, of the entire treatise. Guyton here explains the gain in weight of metals in a manner that seemed to him to reconcile Stahl with Newton: the addition of phlogiston to a metallic calx makes the metal lighter, not because the phlogiston has absolute lightness or "levity," but because it is specifically lighter than air. It did not take his contemporaries long to expose the fallacy in his reasoning; yet some at least did not damn the book for these absurdities but perceived the solid qualities to be found elsewhere in it.

The two historical chapters constitute a valuable survey of the literature on the subject; in them Guyton arrays the authorities in favor of the gain in weight of metals against those who denied the effect in whole or in part. But he insists, like the able lawyer he is, that it is not sufficient, when there is conflicting testimony, merely to add more evidence to one side or the other; it is also

50 Digressions académiques, pp. 10-39. $\quad{ }^{51}$ Ibid., pp. 39-71.

52 Ibid., pp. 72-87.

${ }^{53}$ Partington and McKie, loc. cit., pp. 388-401. 


\section{MYSTERIOUS CALCINATION}

necessary to explain, where possible, the reasons for the divergent testimony of the opposing witnesses. ${ }^{54}$ Thus he accounts for Boulduc's claim that antimony lost weight on calcination by pointing out that the earlier chemist had used a crude sample containing a quarter of its weight of common sulphur. ${ }^{55}$

Guyton was at pains to restrict his own investigations to a smaller number of substances than had been customary in such experiments. He discarded as unreliable all claims (like Homberg's) to have calcined the noble metals, with or without change in weight, suggesting that apparently positive results had been due to impurities and loss of weight to mechanical dispersion by the action of fire. ${ }^{56} \mathrm{He}$ recalled that Robert Boyle claimed to have calcined silver but explained that Boyle had used flaming sulphur as his source of heat and that the fumes of sulphur had probably reacted with the silver ${ }^{57}$ Guyton furthermore discarded all instances of Macquer's "calcination of the first kind," which meant all experiments on limestone, hartshorn, the coraux rouges, and similar substances that had encumbered and confused the earlier reports. Even when confining his study to calcinable metals, Guyton believed it was important to ignore all cases where the metal appreciably volatilizes or sublimes; for this reason he performed no experiments with mercury or with certain of the demimetals, for example, arsenic. ${ }^{58}$

He was quite insistent about the experimental procedures to be followed, rejecting experiments performed with the burning glass as wholly unreliable-though some

54 Digressions académiques, pp. 39-40. $\quad 55$ Ibid., p. 61.

${ }^{56}$ Ibid., pp. 41-45, 51-54. $\quad{ }^{57}$ Ibid., pp. 46-48.

58 Ibid., pp. 66-67. 


\section{LAVOISIER-THE CRUCIAL YEAR}

of the most famous results had been obtained in this way -for in such experiments it is difficult to avoid spattering, fuming, and consequent loss of material. Indeed, Guyton believed that this might explain the extraordinary results reported by Hartsoeker, who kept lead-where the fact of augmentation was so well attested-for several days at the focus of a burning glass without noting any gain in weight. All metals should be calcined, Guyton advised, over an ordinary chemist's fire or in a furnace. ${ }^{59}$

But other experimental precautions must also be carefully observed. Earthenware vessels should be preheated to drive off any moisture and to ensure that they had been properly baked in the manufacture. It is of the utmost importance to carry all calcinations through to completion, for ambiguous results will be obtained if the experimenter uses too feeble a fire or too short an exposure..$^{60}$ During the heating the metal must be freely exposed to the air, for it is a well-known principle-which Guyton confirmed by a control experiment-that calcination (like combustion) cannot take place if air is excluded. Of particular importance, as Guyton learned from his own experience, was the precaution of stirring the melt at regular intervals to expose all parts of it to the air.

Guyton then gives the results of his carefully conducted experiments on the calcination of copper, iron filings, filings of fine English steel, tin, metallic antimony, bismuth, and zinc. ${ }^{61} \mathrm{He}$ did not trouble to confirm the wellknown instance of lead. Weighed samples of each metal were heated in open crucibles or dishes over a fire or under the muffle of a cupellation furnace, using exposures

59 Ibid., pp. 65-66.

${ }^{60}$ Ibid., pp. 63 and 65.

${ }^{61}$ Ibid., pp. 72-87. 
of from one to five hours. All the metals were weighed again after calcination and gave unequivocal evidence of an augmentation in weight. For each metal, when the calcination was brought to completion, he found a characteristic increase in weight. In his experiments with iron filings he followed the progress of the calcination under different conditions by testing the mass at various intervals with a magnet. In the case of the copper filings he showed how the magnitude of the effect varied when the copper was slowly heated and regularly stirred with a polished steel rod, when it was calcined without stirring, and when an attempt was made to calcine it in a covered and hermetically sealed vessel containing only a small amount of air.

The last experiment is worth describing, since the result was certainly such as to interest Lavoisier. Indeed, it may have been to confirm Guyton's result that Lavoisier suggested in the August memorandum an experiment to be carried out with the burning glass and closed vessels to see whether metals could be calcined in a limited amount of air. Guyton placed a half-ounce of copper shavings (rognures de feuilles de cuivre) in a small covered porcelain vessel. This he heated under a muffle for five hours over a fire strong enough to deform the vessel and seal the cover so tightly that it had to be broken to get at the contents. He found hardly any evidence of calcination and noted that the weight of the copper seemed to have decreased by about half a grain, and he concluded that his experiment had confirmed the widely accepted fact that calcination, like combustion, cannot readily occur in closed vessels. ${ }^{62}$ Why this was the case, he did not try to explain. 62 Ibid., pp. 74-75. 


\section{The Reception of Guyton's Experiments}

The historical and experimental parts of Guyton's memoir must command our genuine respect; they constitute a levelheaded, well-conducted piece of quantitative research on a timely problem. And there is little doubt that it settled the basic factual question which chemists were debating and made it as certain as such things can be that the common metals all gain weight when they are calcined.

The influence of Guyton's work was felt well before the appearance in print of the Digressions académiques. As early as the summer of 1771 he submitted his "Dissertation sur le phlogistique" to the Royal Academy of Sciences in Paris, hoping that it might prove acceptable for publication under the Academy's auspices in the next volume of the Mémoires des savants étrangers. Two senior chemists, P. J. Malouin (1701-1777) and the eminent P. J. Macquer, with whom Guyton had been in correspondence since early 1769 , were chosen to read and referee the manuscript.

At a meeting of the Academy of Sciences-held on Saturday, February 8,1772 , in the accustomed rooms in the Louvre-Macquer read a long report on the "Mémoire de M. Demorveau sur le phlogistique," which he had prepared with Malouin. Lavoisier, the young adjoint chimiste, was in attendance and could scarcely have failed to be impressed by what he heard, for the greater part of the session was devoted to Macquer's highly laudatory report. $^{63}$

Macquer described Guyton's essay as a "grand travail ${ }^{63}$ Procès-verbaux, 91 (1772), fols. 31 verso to 36 recto. 
... sur un des objets des plus interessants at des plus élevés de la Chimie." Although the work as a whole was praised for the cogency and clarity of its reasoning, it was the "suite complete des plus belles expériences qui forment le fond de sa dissertation" which aroused special admiration. And the report continued:

On doit distinguer deux objets dans cet ouvrage, l'un sistematique, que nous avons exposé, l'autre expérimental, et tendant uniquement à établir le fait fondamental de l'augmentation du poids absolu des corps par la soustraction de leur principe inflammable; le premier nous parait susceptible de difficultés. ... A l'égard de la partie expérimentale de l'ouvrage de M. de Morveau, elle nous parait mériter les plus grands éloges, et d'autant plus digne d'approbation de l'Académie qu'elle constate et generalize le plus grand nombre des moiëns que peut fournir la chimie un fait très important, jusqu’à présent trop peu décidé et trop particulier. ${ }^{64}$

Here, in the considered judgment of two of the Academy's outstanding chemists, was immediate (and official) recognition that, while the explanation of the phenomenon studied by Guyton was not wholly satisfactory, his experiments had clearly established the reality and generality of a phenomenon about which the evidence had been fragmentary (trop particulier) and contradictory and chemical opinion "trop peu décidé."

Guyton's work was taken up again when the Academy met a week later to hear Macquer conclude his report on the essay. Despite its merits, and because of its length and the author's plan to include the "Dissertation" in a forth-

${ }^{64}$ Ibid., fol. 35 verso. 
coming book, the Academy declined to include it in the next Savants étrangers. This was fair enough; the Digressions académiques must have been nearly ready for the printer and perhaps only awaited the approval of the royal censor; for the approbation, signed by Macquer, is dated March 19, 1772, and the book was in fact published before the month of June. ${ }^{65}$ But Guyton, though denied a double publication, had reason to be satisfied. It was at this meeting of February 15 that the gifted amateur chemist of Dijon, who had been rejected as a candidate six months before, was nominated once again for the post of corresponding member of the Paris Academy; this time he was successfully elected. ${ }^{66}$

Contemporary praise was not confined to the halls of the Louvre, and there is ample evidence that Guyton's "Digressions" was deemed a contribution of real significance. Its influence is immediately traceable in the published literature. In 1773 Baumé-who ten years earlier had expressed doubts about the reality of the augmentation effect-could write in his Chymie expérimentale et

65 So Speter ("Lavoisierana," loc. cit., p. 994). This seems correct, for Macquer presented a copy to the Academy of Sciences on Guyton's behalf at the meeting of June 3, 1772 (Procès-verbaux, 91 [1772], fol. 193 verso). Lavoisier noted this in his plumitif, or personal record of the meeting, remarking that Guyton's book "se vent chez Didot à Paris," a significant expression of his interest. On June 5 Buffon wrote Guyton from Montbard acknowledging a complimentary copy. See Jean Pelseneer, "Une lettre inédite de Buffon à Guyton de Morveau à propos du phlogistique," in Léon Bertin et al., Buffon (Paris, 1952), pp. 133-136.

${ }^{66}$ Ibid., fol. 47 verso. He was duly elected at the meeting of March 7, and made the correspondent of Macquer. Cf. Index biographique des membres et correspondants de l'Académie des sciences, de 1666 d 1939 (Paris, 1939), p. 209. 


\section{MYSTERIOUS CALCINATION}

raisonnée that each type of metal augments in a constant manner during calcination. ${ }^{67}$ An anonymous review of the Digressions académiques, which appeared in the April, 1773, number of the Journal encyclopédique, had high praise for Guyton's experimental work. ${ }^{68}$ And the Marquis de Condorcet, of whose interest in the calcination problem we shall shortly speak, fully appreciated the significance of Guyton's experiments. Writing in 1773 of the increase in the weight of metals on calcination as "un des phénomènes les plus extraordinaires que présente la chimie," Condorcet continued:

M. de Morveau, procureur général au parlement de Dijon, vient de faire sur cet objet des recherches très-étendues: il a prouvé que cette augmentation était réelle et générale pour tous les métaux, ce que quelques chimistes avaient nié. On trouve dans son ouvrage une suite intéressante d'expériences faites avec un soin et une sagacité peu communes, qui le

${ }^{67}$ Baumé, Chymie expérimentale et raisonnée, I, 59, and II, 265. Baumé was at work on his book in the summer of 1772 , for he quotes the Avant-coureur for May 11 (I, 112, note). Yet in the "Avertissement" ( $I$, p. $\mathrm{xx}$ ) he writes with reference to his treatment of phlogiston that this "article étoit imprimé lorsque parut l'excellente Dissertation de M. Guitton [sic] de Morveau, Avocat Général du Parlement de Dijon; sans cette circonstance, jaurois fait usage avec reconnoissance de plusieurs grandes vues que cet habile Physicien propose" (I, 145-161). This refers to the theoretical section of Guyton's work. Though not yet a member of the Academy, Baumé certainly knew, if only through Macquer, of the experimental results which Guyton had reported to the Academy in 1771.

68 "Ce que les chymistes trouveront de meilleur \& de plus essentiel dans cette partie de l'ouvrage de M. de Morveau, ce sont les faits \& les expériences qu'il rapporte sur la réduction [sic] des métaux en chaux" (Journal encyclopédique, April, 1773, p. 87). 
rendront toujours précieux, quand même l'auteur se serait égaré dans la nouvelle explication qu'il propose pour ce phénomène. ${ }^{69}$

The final accolade was accorded a few years later when Macquer, the correspondent and early sponsor of Guyton, wrote as follows on the subject of the calcination of metals in the second and greatly revised edition of his Dictionnaire de chymie (1778):

Nous n'avons encore qu'un très petit nombre de Chymistes modernes qui aient commencé à s'en occuper. Ils ont tourné principalement leurs vues sur un phénomene frappant \& qui paroît appartenir aux chaux métalliques, de quelque maniere que les métaux aient été réduits sous cette forme, je veux parler de l'augmentation de poids très sensible qu'on remarque dans la plupart de ces chaux; je dis la plupart, attendu qu'il n'est pas encore bien constaté que cet effet ait lieu pour tous les métaux; mais enfin, comme on l'a observé dans un grand nombre, ainsi que l'a très bien exposé un Savant, qui a vraiment le génie de la Physique \& de la Chymie, on peut supposer que ce phénomene est général. ${ }^{70}$

In restrospect Guyton himself laid stress on this accomplishment. In 1786 he wrote that if Lavoisier had finally demonstrated the cause of the increase in weight of calcined metals by his "belle expérience" of heating tin

69 Oeuvres de Condorcet, II, 38-39.

${ }^{70}$ P. J. Macquer, Dictionnaire de chymie (2nd ed.; Paris: Chez P. Didot jeune, 1778), I, 346-347. The "savant" is identified in a footnote as "M. de Morveau, Avocat Général au Parlement de Dijon." 


\section{MYSTERIOUS CALCINATION}

and lead in closed vessels, it was he, Guyton, who had first established the reality and the generality of the phenomenon which Lavoisier explained. After a description of Lavoisier's experiment, he wrote:

Les hypothèses proposées pour l'explication de ce phénomène présentoient tant de difficultés, qu'un grand nombre de Physiciens préféroit encore de laisser le fait en question; je crois avoir contribué à en établir la réalité par les expériences nombreuses que je publiai en 1772 (Digressions académiques, $\& c)$, expériences qui, par la conformité des résultats obtenus des divers procédés de calcination \& par les proportions déterminées de cet accroissement de poids suivant la nature de chaque métal, ne permettoient plus de l'attribuer à quelqu'accident. $^{71}$

It is my belief that Lavoisier's interest in the calcination problem was first aroused, not only by meditating about the effervescence of metallic calxes during reduction, but also by the discussions which Guyton's experiments evoked in 1771-1772 and by the evident incompatibility between the newly established fait capital and the phlogiston theory to which Guyton tenaciously adhered. Guyton's procrustean efforts to accommodate theory to experiment, I feel sure, caused Lavoisier to ponder the inherent contradiction and to search for a new explanation of the phenomenon itself. ${ }^{72}$

71 Encyclopédie méthodique-Chimie, I (1786), 699.

72 This interpretation was first set forth in a paper entitled "What Made Lavoisier Study Calcination," read at a meeting of the History of Science Society in New York on December 20, 1948. On this occasion I reported also on Turgot's surprising anticipation of 
If this is so, and if Lavoisier was led in this manner to speculate on the causes of calcination, we might expect to find some testimony to this effect from Lavoisier himself, or at least some reference to the significance of Guyton's experiments.

Yet in print Lavoisier never acknowledged this debt, and indeed scarcely refers to Guyton's early work. There is no mention of Guyton or the Digressions académiques in the Opuscules (1774); and if the man who later became his disciple is several times cited by Lavoisier in his Traité élémentaire de chimie, it is chiefly for Guyton's theories of affinity and his contribution to the reform of chemical nomenclature. In the posthumous Mémoires de chimie (1805), where there is a short history of the calcination problem-and where, of all places, he might be expected to mention Guyton's discovery-Lavoisier merely speaks of Guyton's "efforts infructueux" to explain, by means of the phlogistic hypothesis, the increase in weight of calcined metals; there is no reference to Guyton's experiments. ${ }^{73}$ The sole published evidence I can find for Guyton's influence on Lavoisier is in a paper that the latter read to the Academy in 1783 on the precipitation of metals from their solutions. Here, for three pages, Lavoisier makes use of Guyton's figures for the characteristic increase in weight of the different metals. The experiments are treated with respect, and Guyton is

Lavoisier's discovery. A brief statement of my views concerning Guyton's influence on Lavoisier is given in my recent paper, "Some French Antecedents of the Chemical Revolution," loc. cit., p. 110.

${ }^{73}$ Mémoires de chimie, II, 78; reprinted in Oeuvres de Lavoisier, II, 99-104. Nor is there any reference to Guyton's experiments in Lavoisier's "Rapport à l'Académie sur les travaux de Guyton de Morveau," in Oeuvres, VI, 56-58. 


\section{MYSTERIOUS CALCINATION}

praised for having obtained satisfactory results in the difficult case of zinc. ${ }^{74}$

This is all, and it is not much, from the record printed in Lavoisier's lifetime. Privately, he was more generous. On January 19, 1774, Lavoisier sent Guyton a complimentary copy of his recently published Opuscules, as he did to those others-like the various surviving pioneers in pneumatic chemistry-whose work he had found useful. This would seem to testify to the respect in which Lavoisier held Guyton's book; and, in fact, Lavoisier said as much in the covering letter. After remarking that he would soon be obliged to refute Guyton's theory of the role of phlogiston, he wrote:

Mais en osant attaquer votre oppinion, je declarerai toujours que vos digressions accademiques portent partout lempreinte du genie dobservation, et quon y trouve la Suitte dexperiences la plus Complette la plus interessante la plus exacte qui existe Sur la Calcination des metaux. ${ }^{75}$

It would be hard to state the case more strongly, or in fact more justly; it is regrettable that Lavoisier never said as much in print. That he was not indulging in mere flattery is confirmed by a hitherto unpublished note, which I was fortunate to discover among the Lavoisier papers in the archives of the Academy of Sciences in Paris. It is undated, very short, and worth reproducing in full:

Sur la matiere du feu

Tous les metaux exposes au feu et calcines augmentent de poids tres sensiblement.

74 "Mémoire sur la précipitation des substances métalliques les unes par les autres," Oeuvres de Lavoisier, II, 528-545.

${ }^{75}$ Oeuvres de Lavoisier-Correspondance, II, 404-406. 


\section{LAVOISIER-THE CRUCIAL YEAR}

Les auteurs anciens pretendoient qu'on combinoit du feu avec ces corps dans la calcination et que c'etoit à l'addition de cette Substance pesante qu'on devoit l'augmentation du poids.

Sthal [sic] a pretendu que la calcination enlevoit la matiere du feu aux corps qu'on calcinoit mais lui et ses sectateurs sont tombes dans un labirinte de difficultes comment concevoir en effet qu'on augmente le poids d'un corps en lui enlevant une partie de sa substance.

Quoi qu'il en soit de l'explication, le fait n'en est pas moins constant. Tous les metaux augmentent de poids par la calcination. M. de Morvaux [sic] le demontre complettement dans Ses digressions academiques page 72 jusqu’à $88 .^{76}$

It is likely that this revealing note was written in the summer or early autumn of 1772 , after the publication of the Digressions académiques (which had appeared by early June) but before Lavoisier had carried out those experiments in October which convinced him of the real explanation of the phenomenon. I should guess it to have been written at roughly the same time as the August memorandum.

Guyton's experiments, then, served to convince Lavoisier that the augmentation of the calx was a general effect observed with all calcinable metals, but we know that Lavoisier found utterly preposterous Guyton's attempt to explain the effect in terms of the phlogiston theory. Sometime in the summer of 1772 , before he wrote the August memorandum, several factors which we have

${ }^{76}$ Lavoisier papers, archives of the Academy of Sciences, Paris, dossier 14. This two-page note seems to have been written on paper of the sort Lavoisier used for scattered notes during the period 1772-1773. 


\section{MYSTERIOUS CALCINATION}

suggested-the effervescence of calxes during reduction, the fact (which Guyton had supported) that metals resist calcination in closed vessels, the first inklings of work on gases being carried out abroad, ${ }^{77}$ and Hales's familiar doctrine of fixed air-combined to suggest to Lavoisier a more likely explanation: that the air fixed in metals during calcination and released upon reduction might account for the greater weight of a calx. ${ }^{78}$

77 That in Sweden Torbern Bergman, too, was already working on "fixed air" was known to Lavoisier. Macquer wrote to Bergman on July 18, 1772, that he had announced to the Academy "votre travail sur ce qu'on appelle (sans doute fort improprement) air fixe. elle ne doute pas, d'après l'idée avantageuse qu'elle a conçue de vos talens, par la lecture [in April, 1772] de votre mémoire sur l'or fulminant, que vous ne poussiez très loin cette découverte, et elle en attend le resultat avec empressement." This letter is to appear in Johan Nordström, The Foreign Correspondence of Torbern Bergman, in press. Photocopies of proof sheets were kindly put at my disposal by my friend Dr. Uno Boklund.

${ }^{78}$ Hales might, indeed, have supplied Lavoisier's clue. J. Martin Clare wrote: "The Change of Weight of Bodies in chemical Preparations heretofore presumed to rise from the Adhesion of Particles of Fire, is proved by Dr. Hales, in his Vegetable Staticks, to proceed from the Adhesion of Particles of Air, which he has there shewed to be absorb'd by some Bodies in good Quantities, while it has been generated as fast by others" (Motion of Fluids [3rd ed.; London, 1747], p. 300). 